\title{
Relation of reactive solute-transport parameters to basic soil properties
}

\author{
Md. Abdul Mojid a,*, A.B.M. Zahid Hossain b, Guido C. L. Wyseure c \\ a Department of Irrigation and Water Management, Bangladesh Agricultural University, Mymensingh, Bangladesh \\ b Irrigation and Water Management Division, Bangladesh Rice Research Institute, Gazipur, Bangladesh \\ ${ }^{c}$ Division of Soil and Water Management, Department of Earth and Environmental Sciences, KU Leuven, Celestjnenlaan \\ 200E, 3001 Leuven (Heverlee), Belgium
}

\begin{abstract}
Solute-transport parameters are needed to assess the pollution risks of soil and groundwater resources. A reliable estimate of these parameters from easily measurable soil properties is therefore important. So, the correlations of the transport parameters for one metalloid compound $\left(\mathrm{NaAsO}_{2}\right)$, six heavy metal compounds $\left(\mathrm{Cd}\left(\mathrm{NO}_{3}\right)_{2}, \mathrm{~Pb}\left(\mathrm{NO}_{3}\right)_{2}\right.$, $\mathrm{Ni}\left(\mathrm{NO}_{3}\right)_{2}, \mathrm{ZnCl}_{2}, \mathrm{CuSO}_{4}$ and $\mathrm{Co}\left(\mathrm{NO}_{3}\right)_{2}$ ), two pesticides (cartap and carbendazim) and one inert salt $\left(\mathrm{CaCl}_{2}\right)$ with some basic properties of eight agricultural soils of Bangladesh were investigated. The purpose of this study was to generate information for development of non-parametric pedo-transfer functions for reactive solute transport through soils. The transport experiments with the solutes were done in repacked soil columns under unsaturated steady-state water flow conditions. The major solute-transport parameters velocity of transport $(V)$, dispersion coefficient $(D)$, dispersivity $(\lambda)$, retardation factor $(R)$ and Peclet number $(P)$ - were determined by analysing solute breakthrough curves (BTCs). The basic soil properties pertinent to solute transport: clay content, median grain diameter $\left(D_{50}\right)$, pore-size distribution index $(n)$, bulk density $(\rho)$, organic carbon content (C) and $\mathrm{pH}$ were determined. The associations of the solute-transport parameters with these soil properties were investigated and evaluated. Both the solute dispersivity and retardation factor increased significantly $(\mathrm{p}<0.05)(\lambda$ linearly and $R$ following power law) with the increase in soil clay content. Dispersivity significantly decreased with the increase in median grain diameter following power law. The $V, D, \lambda$ and $P$ values were weakly and negatively correlated with the soil bulk density. Retardation factor, $R$, was moderately and positively correlated with the ratio of clay content to organic carbon content. Dispersivity decreased but $P$ increased, both significantly, with increasing poresize distribution index, $n$. $V, D$ and $P$ were positively correlated with soil $\mathrm{pH}$, while $R$ and $\lambda$ were negatively correlated with it. The correlation of the solute-transport parameters with soil properties being significant $(\mathrm{p}<0.05)$, in most cases, provides strong possibility of predicting solute-transport parameters from the basic soil properties through the development of pedo-transfer functions.
\end{abstract}

\section{Article Info}

Received : 13.01 .2018

Accepted : 14.08 .2018

Keywords: Reactive solutes, transport parameters, soil pH, pore-size distribution.

(c) 2018 Federation of Eurasian Soil Science Societies. All rights reserved

\section{Introduction}

Intensive agriculture with increased use of agrochemicals and other hazardous chemicals (Thawornchaisit and Polprasert, 2009) is continuously raising the pollution level of soils (Muchuweti et al., 2006) and groundwater, especially in the developing countries like Bangladesh. Tannery industries discharge chromium $(\mathrm{Cr})$, silver $(\mathrm{Ag})$, cadmium $(\mathrm{Cd})$, copper $(\mathrm{Cu})$, lead $(\mathrm{Pb})$ and zinc $(\mathrm{Zn})$, while dye effluents contain

\footnotetext{
${ }^{*}$ Corresponding author.

Department of Irrigation and Water Management, Bangladesh Agricultural University, Mymensingh 2202, Bangladesh

Tel.: +8809167401

e-ISSN: $2147-4249$

E-mail address: ma_mojid@yahoo.com DOI: $10.18393 /$ ejss.454512
} 
$\mathrm{Cd}, \mathrm{Cu}, \mathrm{Zn}, \mathrm{Cr}$ and iron (Fe). Applications of some chemical fertilizers and pesticides, and contamination of irrigation water by industry may cause soil pollution by heavy metals and pesticide residues. Increasing use of wastewater and sewage sludge, containing various heavy metals, in irrigation is worsening the problems. Islam et al. (2004) reported elevated concentrations of $\mathrm{As}, \mathrm{Cr}, \mathrm{Cu}, \mathrm{Ni}, \mathrm{Pb}$ and $\mathrm{Zn}$ in many agricultural soils of Bangladesh. As-contaminated groundwater, used for drinking and irrigation, is also a severe problem in large part of Bangladesh.

Solute transport through porous media is important for a wide range of applications, such as groundwater and soil remediation, salt water intrusion, drinking water purification, and wastewater treatment (Pugliese et al., 2015). It is also important for plant growth, chemical reactions (such as sorption, precipitation and redox) and for understanding the environmental impact of waste dumping sites and surface-applied chemicals, such as pesticides and fertilizers (Karup et al., 2016). So, characterization of the solute-transport process through soils is an important aspect, specifically for assessing the pollution of soil and groundwater resources. For an accurate assessment, solute-transport parameters, such as velocity of transport, dispersion coefficient, dispersivity and retardation factor need to be determined. These parameters are needed for modelling of water and solute movement in field soils and aquifers. These models can guide both future research efforts and current management practices in an objective and quantitative manner. They are also needed for the design of waste disposal sites (industrial and municipal), long-term management of various harmful substances (e.g., radioactive waste) (Filipović et al., 2016), optimum application of agrochemicals in the field, selection and design of suitable leaching methods, and monitoring quality of soil and groundwater resources over time. The success of these models, however, depends on the ability to quantify properly the solute-transport parameters to be used in the models.

Practically, it is not possible to measure the solute-transport parameters for a large number of soils under nearly infinite variety of field conditions since their direct measurement is time consuming, cumbersome and costly. Often, the use of field technologies is not a suitable option to study solute transport in soil due to their temporal and spatial limitations and high cost. Laboratory experiments and modelling can be good alternatives (Filipović et al., 2016). However, temporal and spatial variability in soil physical properties has a considerable effect on model results. So, it is necessary to know the transport behaviour of different solutes through various soil types. But, because of large time and high cost, the majority of the techniques for direct measurement of solute-transport parameters are restricted to small scales (Darcy scale and smaller) only. So, it is not possible to map solute-transport properties at larger scales by direct measurements. However, Koestel et al. (2013), through a comprehensive review of 733 breakthrough curves, reported the possibility of a way out by using proxy variables like soil texture, bulk density, or land use to estimate soil solute-transport properties. The essence of this possibility is that good predictions, instead of direct measurements, may be accurate enough for many practical applications.

The transport behaviour of solutes in soils is governed by a variety of complex and dynamic physical, chemical and biological processes. Particle size distribution, bulk density, structure and $\mathrm{pH}$ of the soils also greatly influence solute transport (Karup et al., 2016). Li et al. (2009) reported weak negative relation between velocity of solutes and bulk density of soils, while Montoya et al. (2006) reported a strong positive correlation $(r=0.91)$ between velocity of solutes and clay content for soil columns from non-tillage land. $\mathrm{Li}$ et al. (2009) and Tabarzad et al. (2011) reported positive relationship between solute dispersion coefficient and bulk density. But, contrasting result was observed by Bromly et al. (2007) that was supported by Montoya et al. (2006) and Okada et al. (2014); they observed a strong positive correlation $(r=0.80)$ between dispersion coefficient and clay content in well-structured soil samples under no-tillage condition. Bromly et al. (2007) reported significant negative correlation between dispersivity and bulk density, while Xu and Eckstein (1997) reported a directly related dispersivity with median grain size, $\mathrm{D}_{50}$, for uniform classic materials with a uniformity coefficient $<2$. Hussein (2009), on the other hand, obtained linear relation between $\mathrm{D}_{50}$ and effective molecular diffusion coefficient of solutes. Nemeth-Konda et al. (2002) observed positive correlations of adsorption coefficients with soil clay content and organic carbon for carbendazim. The ratio between the clay content and organic carbon content was also hypothesized as a fundamental control of the structure of agricultural topsoil and consequently for the solute transport properties (de Jonge et al., 2009).

Despite substantial amount of field and laboratory data on the transport of solutes in soils obtained in the recent decades in different countries, the methods for assessing the chemical parameters from the physical properties of soils remain poorly developed (Raymundo-Raymundo et al., 2012). In the comprehensive review, Koestel et al. (2012) analysed information on 733 BTCs, all of which were for inert/conservative 
tracers, mostly, on undisturbed soil samples and a smaller number on columns filled with glass beads, clean sands, or sieved and repacked soil. But, the transport behaviour of the inert solutes in soils is markedly different from the reactive solutes (Mojid and Vereecken, 2005a,b). For example, because of the adsorption of reactive solutes by the soil particles, their transport velocity is slower than the inert solute (Taran et al., 2015). Models to estimate solute transport in soils are often soil-specific and simply cannot be extrapolated to soils with a different texture. Furthermore, for establishing relationships between soil properties and solute-transport properties, it is important to focus on small scales since the small-scale relationships are very likely fundamental to corresponding relationships at larger scales (Vogel and Roth, 2003). Such relationships for soils, especially agricultural soils of Bangladesh, are yet to be investigated. So, the objective of this study was to investigate relationships of some soil properties with solute-transport parameters. The main motivation for this work was to create a dataset of reactive solute-transport properties to enable the future development of non-parametric pedo-transfer functions, especially for reactive solute transport.

\section{Material and Methods}

\section{Site selection and soil sampling}

Soil samples were collected from seven administrative districts of Bangladesh - Mymensingh, Gazipur, Comilla, Satkhira, Bogra, Rajshahi and Dinajpur, the corresponding Agro-Ecological Zone (AEZ) being 9, 28, 19, 13, 25, 11 and 3 (BARC, 2008). Total eight soil samples, taking two samples from Mymensingh and one from each of the other districts, were collected. As ploughing upper soil layers $(\approx 15 \mathrm{~cm})$ is a common practice at the selected locations and soil structure is affected during irrigation and rainfall, repacked soil columns were used to determine solute-transport parameters to reduce variability due to heterogeneity. Soil samples were collected from $0-15 \mathrm{~cm}$ top soil layer covering an area of one square meter. The soils were air dried and passed through a 2-mm mesh sieve after crushing; soils with aggregate size of $\approx 2 \mathrm{~mm}$ are regarded representative for characterizing reliable physical quality indicators (Stavi et al., 2011). Subsamples of the soils were analysed for texture, grain size, electrical conductivity (EC), pH and organic carbon (C) following standard methods (Page et al., 1982).

\section{Selection of solutes}

Based on composition of the most frequently used agrochemicals and waste products discharged by industry, and problem of groundwater contamination by arsenic (As) in Bangladesh, one metalloid (As), six heavy metals $(\mathrm{Cd}, \mathrm{Ni}, \mathrm{Pb}, \mathrm{Co}, \mathrm{Zn}$ and $\mathrm{Cu})$ and, for comparison, laboratory grade calcium chloride $\left(\mathrm{CaCl}_{2}\right)$ were used for the transport experiments. In addition, cartap and carbendazim, extensively used as insecticide and fungicide, respectively, were selected as organic solutes. Tables 1 and 2 provide some properties of the selected chemicals.

Table 1. Chemical formula, molecular weight, electrical conductivity (EC) and form of $\mathrm{CaCl}_{2}, \mathrm{NaAsO}_{2}, \mathrm{~Pb}\left(\mathrm{NO}_{3}\right)_{2}$, $\mathrm{Cd}\left(\mathrm{NO}_{3}\right)_{2}, \mathrm{ZnCl}_{2}, \mathrm{CuSO}_{4}, \mathrm{Ni}\left(\mathrm{NO}_{3}\right)_{2}$ and $\mathrm{Co}\left(\mathrm{NO}_{3}\right)_{2}$

\begin{tabular}{|c|c|c|c|c|c|c|}
\hline Sl. No & Solute & Metal salt & Formula & 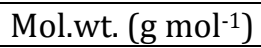 & $* \mathrm{EC}\left(\mathrm{mS} \mathrm{m}^{-1}\right)$ & Form \\
\hline 1 & $\mathrm{Ca}$ & Calcium chloride & $\mathrm{CaCl}_{2} \cdot 2 \mathrm{H}_{2} \mathrm{O}$ & 147.02 & 166 & Powder \\
\hline 2 & As & Sodium arsenite & $\mathrm{NaAsO}_{2}$ & 312.01 & 236 & Granular \\
\hline 3 & $\mathrm{~Pb}$ & Lead nitrate & $\mathrm{Pb}\left(\mathrm{NO}_{3}\right)_{2}$ & 331.21 & 213 & Powder \\
\hline 4 & $\mathrm{Cd}$ & Cadmium nitrate & $\mathrm{Cd}\left(\mathrm{NO}_{3}\right)_{2} \cdot 4 \mathrm{H}_{2} \mathrm{O}$ & 308.47 & 207 & Crystal \\
\hline 5 & $\mathrm{Zn}$ & Zinc chloride & $\mathrm{ZnCl}_{2}$ & 136.28 & 152 & Powder \\
\hline 6 & $\mathrm{Cu}$ & Copper sulphate & $\mathrm{CuSO}_{4} .5 \mathrm{H}_{2} \mathrm{O}$ & 249.68 & 116 & Crystal \\
\hline 7 & $\mathrm{Ni}$ & Nickel nitrate & $\mathrm{Ni}\left(\mathrm{NO}_{3}\right)_{2} \cdot 6 \mathrm{H}_{2} \mathrm{O}$ & 290.81 & 211 & Crystal \\
\hline 8 & Co & Cobalt nitrate & $\mathrm{Co}\left(\mathrm{NO}_{3}\right)_{2} \cdot 6 \mathrm{H}_{2} \mathrm{O}$ & 291.03 & 153 & Crystal \\
\hline
\end{tabular}

${ }^{*}$ EC was measured at concentration $5 \mathrm{mM} \mathrm{l}^{-1}$.

Table 2. Molecular weight, solubility, electrical conductivity (EC) and form of cartap and carbendazim pesticides

\begin{tabular}{llcccc}
\hline $\begin{array}{l}\text { Active } \\
\text { ingredient }\end{array}$ & Chemical group & $\begin{array}{c}\text { Commercial } \\
\text { name }\end{array}$ & $\begin{array}{c}\text { Mol. wt. } \\
\left(\mathrm{g} \mathrm{mol}^{-1}\right)\end{array}$ & $\begin{array}{c}\text { Solubility (water) } \\
\left(\mathrm{mg} \mathrm{l}^{-1}\right)\end{array}$ & $\begin{array}{c}\text { *EC } \\
\left(\mathrm{mS} \mathrm{m}^{-1}\right)\end{array}$ \\
\hline Cartap & Cartap hydrochloride & Bravo & 273.8 & $2.0 \times 10^{5}$ & 241 \\
Cabendazim & Carbamate-benzimidazole & Bavistin & 191.2 & 8.0 & $\begin{array}{c}\text { Powder } \\
\text { Granular }\end{array}$ \\
\hline
\end{tabular}

Source: Shanghai Skyblue Chemical Co. Ltd., China

* EC was measured at concentration $5 \mathrm{mM}$.

\section{Solute-transport experiments}

The experimental set-up and conduction of solute-transport experiments were described in Mojid et al. (2016); only a summary is provided here. Four PVC columns (each $1.2 \mathrm{~m}$ high, $0.2 \mathrm{~m}$ in diameter and with 
the bottom closed) were set on a wooden pallet and uniformly filled with a sandy loam soil. These columns, to be used for supporting experimental soil columns, were allowed to attain stable structure by alternate wetting and drying over one year. Following Mojid et al. (2004), four additional PVC columns (each $34 \mathrm{~cm}$ long and $15 \mathrm{~cm}$ in inner diameter) were filled uniformly and compactly up to $32 \mathrm{~cm}$ depth with air-dried and sieved soils to be used for solute-transport experiments. Tap water $\left(E C=17 \mathrm{mS} \mathrm{m}^{-1}\right)$ was applied from the bottom upwards by placing the soil columns in a large flat-bottom plastic bowl. After settlement and forming structure in six months, sufficient quantity of tap water was leached through the soil columns following six wetting and drying cycles in the next three months. The columns were then transferred to the top of the 1.2m supporting soil columns and placed vertically. The remaining four soils were used in the second batch of similar experiments.

Two 3-rod TDR sensors $(10 \mathrm{~cm}$ long, $3 \mathrm{~cm}$ spacing of centre to centre of the outer rods and $0.2 \mathrm{~cm}$ rod diameter) were inserted horizontally to each column and glued to make water proof. One sensor was at $8 \mathrm{~cm}$ and the other at $28 \mathrm{~cm}$ below the top of the upper columns. Measuring concentrations between the two sensors within a sample rather than from the top of the sample to one sensor provided several advantages (Mojid et al., 2006). A cartridge pump applied tap water at a constant rate $\left(0.32 \pm 0.02 \mathrm{~cm} \mathrm{~h}^{-1}\right)$, which was lesser than the saturated hydraulic conductivities of the soils, ensuring unsaturated flow. At steady-state condition, a pulse of $5 \mathrm{ml} \mathrm{CaCl}_{2}$ solution $\left(250 \mathrm{~g} \mathrm{l}^{-1}\right)$ was introduced uniformly on each column by a syringe. A TDR100 and CR10X datalogger recorded water content and bulk EC of the soils at pre-selected intervals; the EC is a proxy of breakthrough concentration of the solutes. The measurements continued until whole of the applied solute leached out from the upper columns. Measurements of water content and bulk EC were conducted sequentially for the ten solutes (Table 1 and 2) in the same soil column according to the order: $\mathrm{Ca}$, cartap, $\mathrm{Ni}, \mathrm{Cu}, \mathrm{Zn}, \mathrm{Pb}$, carbendazim, $\mathrm{Cd}$, Co and As. The pulse volume and concentration for all the solutes were the same as that for $\mathrm{CaCl}_{2}(5 \mathrm{ml})$. After completion of the experiments with the eight soils in two batches, six soil samples were collected from the top $5 \mathrm{~cm}$ of each column using 5 -cm diameter core samplers.

\section{Soil analysis}

Soil particle size distribution was determined by Hydrometer Method (Page et al., 1982) and textures of the soils were determined there from. The $\mathrm{EC}$ and $\mathrm{pH}$ of the soils were determined by a glass electrode $\mathrm{pH}$ meter, and organic matter was determined by Walkey-Black method as outlined by Jackson (1962). Gradation tests of the soils were done on the samples by a typical sieve analysis involving a nested column of

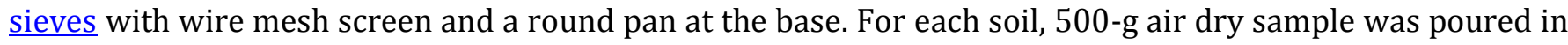
the top sieve; each lower sieve in the column had smaller openings than the one above. After shaking the sieves with an electrical shaker, the soil particles retained on each sieve were weighed separately. This test was done in accordance with the British Standards, BS 1377 (1990) (Code of Practice) for the eight soils. The effective grain size $\left(D_{10}\right)$, median grain diameter $\left(D_{50}\right)$, grain diameter at $60 \%$ passing $\left(D_{60}\right)$ and uniformity coefficient $\left(\mathrm{C}_{\mathrm{u}}\right)$ were calculated from the particle size distribution curves of the soils. The $\mathrm{C}_{\mathrm{u}}$, considered as a shape parameter, was calculated by

$$
C_{u}=\frac{D_{60}}{D_{10}}
$$

The bulk densities of the soils $(\rho)$ in the experimental columns were determined by core cutter method (BS 1377 (1990)). Three of the soil samples in the core samplers from each column were dried in oven at $105^{\circ} \mathrm{C}$ for $24 \mathrm{~h}$. The bulk densities of the soils were determined by dividing the oven dry weights of the soils by the volume of the cores.

\section{Soil-water retention}

Soil-water retention data were measured on the remaining three soil samples in the core samplers for each column. A sandbox (Eijkelkamp, The Netherlands) was used to measure water retention data at low matric suction $(<100 \mathrm{~cm})$. Water retention data at higher matric suctions $(200,300,500,1000,1700,3000,8000$, 12000 and $15000 \mathrm{~cm}$ ) were determined by using a pressure plate apparatus (Soil Moisture Equipment Corp., Santa Barbara, CA-850-964-3525). The samples used for the sandbox and pressure plate apparatus were weighed after they reached equilibrium at each suctions. Finally, the soil samples were dried in oven at 105 ${ }^{0} \mathrm{C}$ for $24 \mathrm{~h}$. From the difference in weights of the samples at the end of different suctions and those after drying in oven, the water contents of the samples against the applied suctions were calculated. By plotting the water contents against the corresponding matric suctions, the soil-water retention curves for the samples were obtained. 
Soil-water retention model of van Genuchten (1980) was fitted to the soil-water retention curves by using nonlinear least-squares optimization approach. The model is given by

$$
\theta=\theta_{r}+\frac{\theta_{s}-\theta_{r}}{\left[1+(\alpha h)^{n}\right]^{m}}
$$

where $\theta_{\mathrm{s}}$ and $\theta_{\mathrm{r}}$ are the saturated and residual soil-water contents, respectively, $\theta$ is the gravimetric water content $\left(\mathrm{g} \mathrm{g}^{-1}\right), h$ is the matric suction $(\mathrm{cm}), \alpha$ is the inverse of matric suction at the inflection point of the retention curves, and $m$ and $n$ are parameters that govern shape of the fitted curves. The van Genuchten's $n$ (Eq.2) is a measure of pore-size distribution index and considers the slope of desaturation zone of the soilwater retention curve (Mosaddeghi et al., 2008). However, Guber et al. (2004) suggested that the physical correlate of $n$ is the impact content of small aggregates in a soil. A large $n$ indicates dominancy of small pores in the total porosity. So, $n$ can be treated as a measure of the increase or decrease of micro-porosity in soils. The minimization function is expressed by

$$
F(\alpha, n, m)=\sum_{i=1}^{m_{1}}\left(\theta_{\text {meas }, i}-\theta_{i}\right)^{2}
$$

where $m_{1}$ is the number of measured points on the water retention curve, $\theta_{\text {meas, }, i}$ is the measured and $\theta_{i}$ is the corresponding estimated value calculated by Eq. 2.

\section{Breakthrough curve analysis}

The analysis of TDR-measured EC is based on the relation between the concentration of a solute in soil water and the EC of soil water, which is linearly related to the EC of bulk soil for constant soil-water content (Ward et al., 1994). Thus, solute BTCs were constructed from the time series of TDR-measured bulk soil EC. For the details of BTC analysis, the readers are referred to Mojid et al. (2016). In brief, the mean travel time $(\tau)$, mass-dispersion number $(\mathrm{N})$, and retardation factor, $R$, of the solutes were optimized from the BTCs by a transfer-function method (Mojid et al., 2004; their Equations 5 and 7). $\mathrm{For}^{\mathrm{CaCl}}$, $R$ was fixed at unity considering it to be a non-reactive solute. The other solute-transport parameters $-V, D$ and $\lambda$ - were calculated from $\tau, \mathrm{N}$ and the distance, $\mathrm{Z}$, between the input and response BTCs that were measured at the top and bottom TDR sensors. $P$ was calculated by $\mathrm{ZV} / D$. For the physical meaning of $V$ and $R$ for the reactive solutes (all solutes in this study except $\mathrm{CaCl}_{2}$ ), the readers are referred to Mojid and Vereecken (2005b). Pearson correlation coefficients, along with their significance (for $\mathrm{p}<0.05$ ), were calculated to evaluate relationships among the solute-transport parameters and basic soil properties.

\section{Results and Discussion}

\section{Basic soil properties}

The sand, silt and clay content of the soils (Table 3) ranged over $4.92-79.48 \%, 14.48-77.96 \%$ and $6.04-$ $19.12 \%$, respectively. Five of the eight soils were silt loam; one was loamy sand, one sandy loam and one silt. The dry bulk density, $\rho$, of the repacked soils in the experimental columns varied from 1.29 to $1.40 \mathrm{~g} \mathrm{~cm}^{-3}$ (Table 3); the variation of bulk density was due to the soil textural variation, not due to variation in compaction. The narrow range of bulk density in the soils was due to the closer textural classes of the soils.

\begin{tabular}{|c|c|c|c|c|c|c|}
\hline Locations & Textural class & $\begin{array}{ll}\text { USDA } & \text { classification } \\
(1978) & \end{array}$ & $\begin{array}{c}\text { Clay content } \\
(\%)\end{array}$ & $\begin{array}{l}\text { Bulk density } \\
\left(\mathrm{g} \mathrm{cm}^{-3}\right)\end{array}$ & $\begin{array}{c}\text { Organic } \\
\text { carbon (\%) }\end{array}$ & $\mathrm{pH}$ \\
\hline Mymensingh (1) & Loamy sand & Aeric Haplaquepts & 6.04 & 1.36 & 0.767 & 7.36 \\
\hline Mymensingh (2) & Silt loam & Aeric Haplaquepts & 11.44 & 1.33 & 0.686 & 7.45 \\
\hline Dinajpur & Sandy loam & Udic Ustochrepts & 8.50 & 1.33 & 0.452 & 7.58 \\
\hline Bogra & Silt loam & Aeric Fluvaquents & 10.68 & 1.29 & 0.753 & 7.38 \\
\hline Gazipur & Silt loam & Aeric Fluvaquents & 12.68 & 1.40 & 0.523 & 7.01 \\
\hline Rajshahi & Silt & Aquic Eutrochrepts & 13.36 & 1.34 & 0.787 & 7.07 \\
\hline Comilla & Silt loam & Aquic Udifluvents & 15.48 & 1.37 & 0.372 & 6.32 \\
\hline Satkhira & Silt loam & Aquic Eutrochrepts & 19.12 & 1.32 & 0.840 & 6.85 \\
\hline
\end{tabular}

Table 3. Textural class, clay content, bulk density, organic carbon content and pH of soils

For soils with similar textures, $\rho$ is regarded as a strong predictor for structural variation in the soils (Norgaard et al., 2013). The bulk density was weakly and negatively correlated $(r=-0.014)$ with \%clay of the 
soils. It decreased insignificantly $(r=-0.51 ; \mathrm{p}<0.05)$ with the increase in organic carbon, C. Relatively low and narrow range of organic carbon $(0.37$ to $0.84 \%)$ and clay content $(6.04-19.12 \%)$ of the soils might limit complete exposure of their roles in solute transport through the soils. Soil pH ranged from slightly acidic (6.32) to slightly alkaline (7.58). It was strongly and negatively correlated ( $r=-0.71)$ with clay content of the soils. The effective grain diameter $\left(D_{10}\right)$, median grain diameter $\left(D_{50}\right)$ and grain diameter at $D_{60}$ of the soils ranged from 0.028 to $0.085 \mathrm{~mm}, 0.062$ to $0.235 \mathrm{~mm}$ and 0.079 to $0.278 \mathrm{~mm}$, respectively (Table 4). The uniformity coefficient $\left(\mathrm{C}_{\mathrm{u}}\right)$ of the soils was within 2.63-3.86, implying that the soils were well-graded $\left(\mathrm{C}_{\mathrm{u}}>\right.$ 2.0; Arora, 2000) with a good drainage environment.

Table 4. Effective grain size $\left(D_{10}\right)$, median grain diameter $\left(D_{50}\right)$, grain diameter at $60 \%$ passing $\left(D_{60}\right)$ and uniformity coefficient $\left(\mathrm{C}_{\mathrm{u}}\right)(\mathrm{n}=8)$

\begin{tabular}{lcccc}
\hline Locations & $\mathrm{D}_{10}(\mathrm{~mm})$ & $\mathrm{D}_{50}(\mathrm{~mm})$ & $\mathrm{D}_{60}(\mathrm{~mm})$ & $\mathrm{C}_{\mathrm{u}}(-)$ \\
\hline Mymensingh (1) & 0.085 & 0.235 & 0.278 & 3.27 \\
Mymensingh (2) & 0.048 & 0.101 & 0.157 & 3.26 \\
Dinajpur & 0.073 & 0.200 & 0.261 & 3.58 \\
Bogra & 0.052 & 0.112 & 0.173 & 3.30 \\
Gazipur & 0.035 & 0.095 & 0.135 & 3.86 \\
Rajshahi & 0.029 & 0.069 & 0.085 & 2.98 \\
Comilla & 0.031 & 0.066 & 0.082 & 2.63 \\
Satkhira & 0.028 & 0.062 & 0.079 & 2.78 \\
\hline
\end{tabular}

\section{Solute transport as affected by soil properties}

\section{Transport velocity as affected by soil bulk density and clay}

The velocity of the solutes, $V$, through the unsaturated soil columns varied inversely with bulk density, $\rho$, of the soils, revealing that soil clay enhanced solute movement through the soils. The correlation between $V$ and $\rho(r=-0.047$ to -0.101$)$ was insignificant $(\mathrm{p}<0.05)$. It is noted that although the correlation matrices were determined and tabulated with the Pearson correlation coefficients for all the solutes under investigation, only that for $\mathrm{NaAsO}_{2}$ is provided in Table 5 as an example. During conditioning of our repacked soil columns by alternate wetting and drying, the soils attained structure, the level of which varied on the quantity of clay content; the soil with higher clay content attained better structure than the one with lower clay content. Over the narrow range of clay content $(6.04-19.12 \%)$ in the soils, the movement of the solutes was dominantly governed by the level of soil structural development than by the texture of the soils. The observed velocity of the solutes suggests that clay content in soils under conservational tillage would favour the transport of solutes since it augments solute velocity through soil structural improvement.

Table 5. Correlation matrices (Pearson correlation coefficients) of velocity $(V)$, dispersion coefficient $(D)$, dispersivity $(\lambda)$, retardation factor $(R)$ and Peclet number $(P)$ of $\mathrm{NaAsO}_{2}$ and bulk density $(\rho)$, organic carbon content $(C)$, clay content, $\mathrm{pH}$, effective grain size $\left(\mathrm{D}_{50}\right)$ and uniformity coefficient $\left(\mathrm{C}_{\mathrm{u}}\right)$ of eight soils

\begin{tabular}{|c|c|c|c|c|c|c|c|c|c|c|c|}
\hline Parameters & $\begin{array}{c}V \\
\left(\mathrm{~cm} \mathrm{~h}^{-1}\right)\end{array}$ & $\begin{array}{c}D \\
\left(\mathrm{~cm}^{2} \mathrm{~h}^{-1}\right) \\
\end{array}$ & $\begin{array}{c}\lambda \\
(\mathrm{cm})\end{array}$ & $R$ & $P$ & $\begin{array}{c}\rho \\
\left(\mathrm{g} \mathrm{cm}^{-3}\right)\end{array}$ & $\begin{array}{c}\mathrm{C} \\
(\%) \\
\end{array}$ & $\begin{array}{l}\text { Clay } \\
(\%)\end{array}$ & $\mathrm{pH}$ & $\begin{array}{l}\mathrm{D}_{50} \\
(\%) \\
\end{array}$ & $\mathrm{C}_{\mathrm{u}}$ \\
\hline$V$ & 1 & & & & & & & & & & \\
\hline$D$ & $0.93^{*}$ & 1 & & & & & & & & & \\
\hline$\lambda$ & $-0.99 *$ & $-0.88^{*}$ & 1 & & & & & & & & \\
\hline$R$ & $-0.98^{*}$ & $-0.88^{*}$ & $0.99 *$ & 1 & & & & & & & \\
\hline$P$ & $0.98^{*}$ & $0.85^{*}$ & $1.00^{*}$ & $-0.98^{*}$ & 1 & & & & & & \\
\hline$\rho$ & -0.05 & 0.04 & 0.12 & 0.10 & -0.10 & 1 & & & & & \\
\hline C & 0.02 & -0.11 & -0.09 & 0.05 & 0.09 & -0.51 & 1 & & & & \\
\hline Clay & $-0.99 *$ & $-0.95^{*}$ & $0.96^{*}$ & $0.97 *$ & $-0.95^{*}$ & -0.01 & 0.07 & 1 & & & \\
\hline $\mathrm{pH}$ & $0.76^{*}$ & $0.72^{*}$ & $-0.79 *$ & $-0.73^{*}$ & $0.74^{*}$ & -0.51 & 0.40 & -0.71 & 1 & & \\
\hline $\mathrm{D}_{50}$ & $0.93^{*}$ & $0.75^{*}$ & $0.95^{*}$ & $-0.96 *$ & $0.97^{*}$ & 0.01 & -0.05 & $-0.89 *$ & 0.59 & 1 & \\
\hline $\mathrm{C}_{\mathrm{u}}$ & 0.59 & 0.67 & -0.58 & -0.54 & 0.53 & 0.24 & -0.18 & -0.59 & 0.61 & 0.47 & 1 \\
\hline
\end{tabular}

${ }^{*}$ Correlation is significant for $\mathrm{p}<0.05$ (2-tailed).

\section{Dispersion coefficient as affected by bulk density and clay content}

Solute dispersion coefficient, $D$, was mostly independent of soil bulk density, $\rho$, providing insignificant relationship between them $(r=0.02-0.17)$. Several contrasting results were, however, reported regarding the role of $\rho$ on $D$ : Li et al. (2009) observed power law relation between $D$ and $\rho$, Bromly et al. (2007) 
observed significant negative correlation between them, while Tabarzad et al. (2011) reported a decrease in $D$ in clay loam soils compared to sandy loam and silt loam, implying a linear relation between $D$ and $\rho$. The later observation is similar to our observation. Okada et al. (2014), on the other hand, found positive correlation between $D$ and clay content in no till samples; they did not observe such relation in conventional tillage samples. As mentioned before that because of closer textural classes of the soils under investigation, the bulk density variation was relatively small (1.29 to $1.40 \mathrm{~g} \mathrm{~cm}^{-3}$, Table 3). But, using soils with large textural variation and hence with a wide bulk density range would probably reveal the complete role of $\rho$ on $D$.

\section{Dispersivity as affected by clay content and median grain diameter}

Figure 1 illustrates that dispersivity of the reactive solutes, $\lambda$, is strongly and significantly $(\mathrm{p}<0.05)$ correlated with clay content of the soils $(r=0.91-0.98)$ following power law; for non-reactive $\mathrm{CaCl}_{2}$, the correlation $(r=0.37)$ is insignificant. Such correlation between $\lambda$ and \%clay reveals that soil clay can be a promising predictor of solute dispersivity. This proposition is also substantiated by Bromly et al. (2007) who reported clay content as the most important controlling factor of $\lambda$. Soil bulk density plays only insignificant role on $\lambda$. Figure 2 depicts power law decrease of $\lambda$ with the increase in median grain diameter $\left(D_{50}\right)$ of the soils except for $\mathrm{CaCl}_{2}$. Similar to $\mathrm{Xu}$ and Eckstein (1997), the effect of $\mathrm{D}_{50}$ on $\lambda$ gradually decreased in relatively heterogeneous materials $\left(C_{u}>2\right)$. The correlation $(r=0.88-0.97)$ between $\lambda$ and $D_{50}$ was significant $(p<0.05)$, which exposed that $D_{50}$ could be an important predictor of solute dispersivity. Dispersivity also decreased linearly with the increase in pore-size distribution index, $n$ (Figure 3 ). The significant correlations between $\lambda$ and $n$ ( $r=0.89-0.99$ ) implied that $n$ could also be a potential predictor of $\lambda$. It is noted that since organic carbon improves soil aggregation and structure, the relationship between dispersivity and soil properties might become obscured by perturbations due to its presence in the soils. However, the organic carbon contents in the soils under investigation being low (0.37-0.84) might not cause considerable perturbations in the observed results.

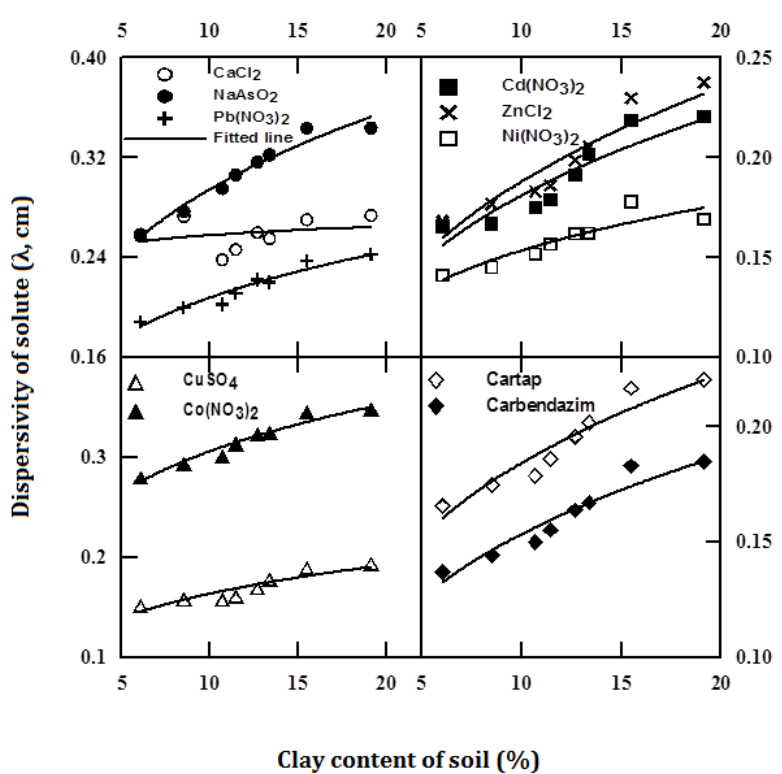

Figure 1. Effects of clay content on the dispersivity of different solutes through different soils at average water flux of $0.32 \mathrm{~cm} \mathrm{~h}^{-1}$.

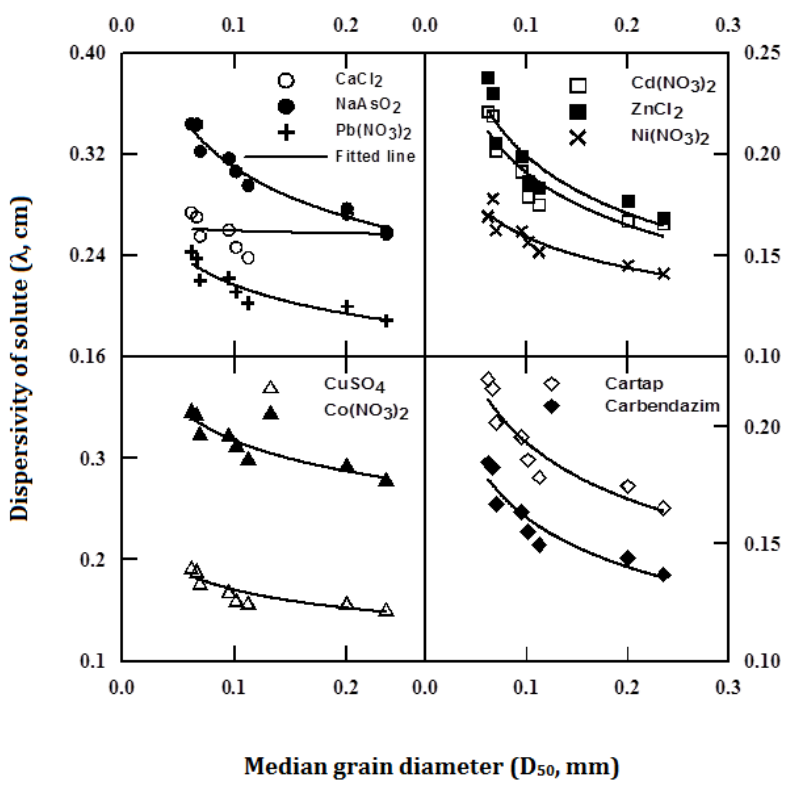

Figure 2. Relationship between dispersivities $(\lambda, \mathrm{cm})$ and median grain diameters $\left(D_{50}\right)$ of different textured soils for different solutes at average water flux of $0.32 \mathrm{~cm} \mathrm{~h}^{-1}$.

\section{Peclet number and retardation factor as affected by soil properties}

Pore-size distribution index, $n$, strongly influenced $P$, which increased linearly with the increase in $n$ (Figure 4). The significant correlations between $P$ and $n(r=0.82-0.99)$ implied that $n$ could be a reliable predictor of $P$. The clay content of the soils, by enhancing solute adsorption in the soils, considerably augmented the retardation factors. Figure 5 illustrates the increase in $R$ with the increase in \%clay content following power law with significant correlation $(r=0.92-0.98)$. Calcium chloride is an inert solute having an ideal retardation factor of unity. 


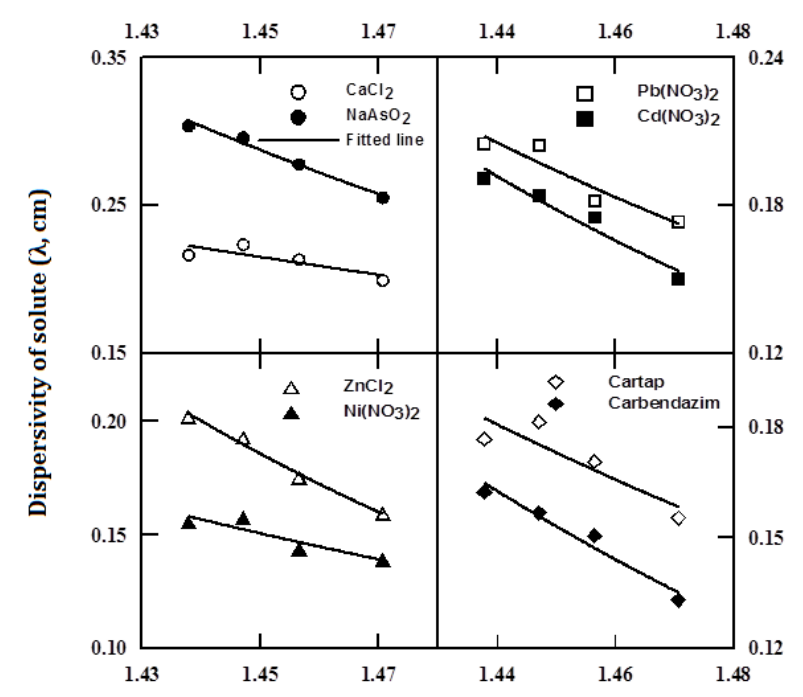

Pore-size distribution index (n)

Figure 3. Decrease in dispersivity $(\lambda)$ of different solutes in soils due to increase pore size distribution index $(n)$ after treatment with wastewater at average water flux of $0.33 \mathrm{~cm} \mathrm{~h}^{-1}$

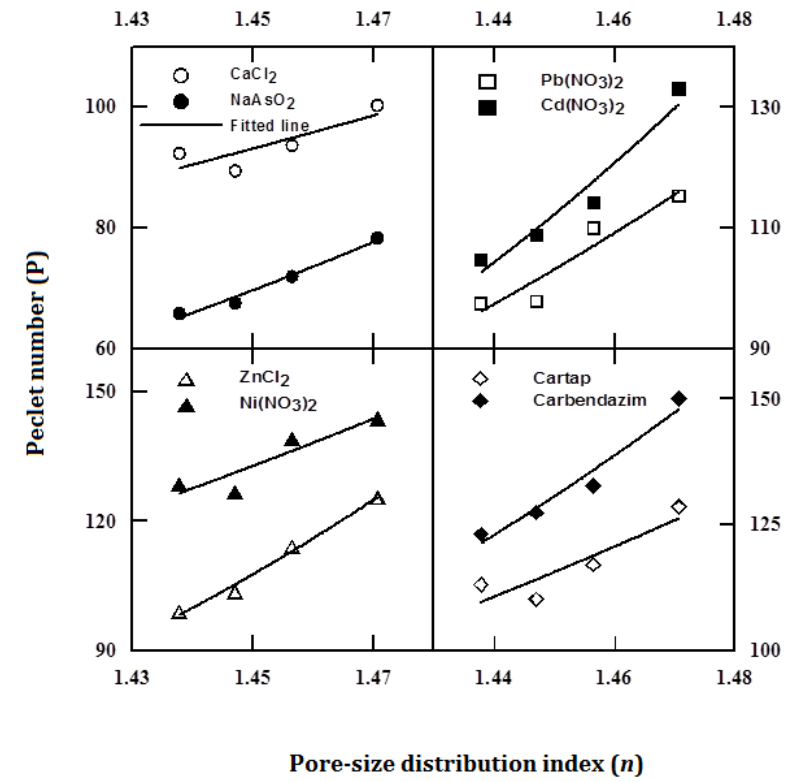

Figure 4. Variation of Peclet number $(P)$ with pore size distribution index $(n)$ for different soils treated with fresh water and wastewater at average water flux of $0.33 \mathrm{~cm} \mathrm{~h}^{-1}$

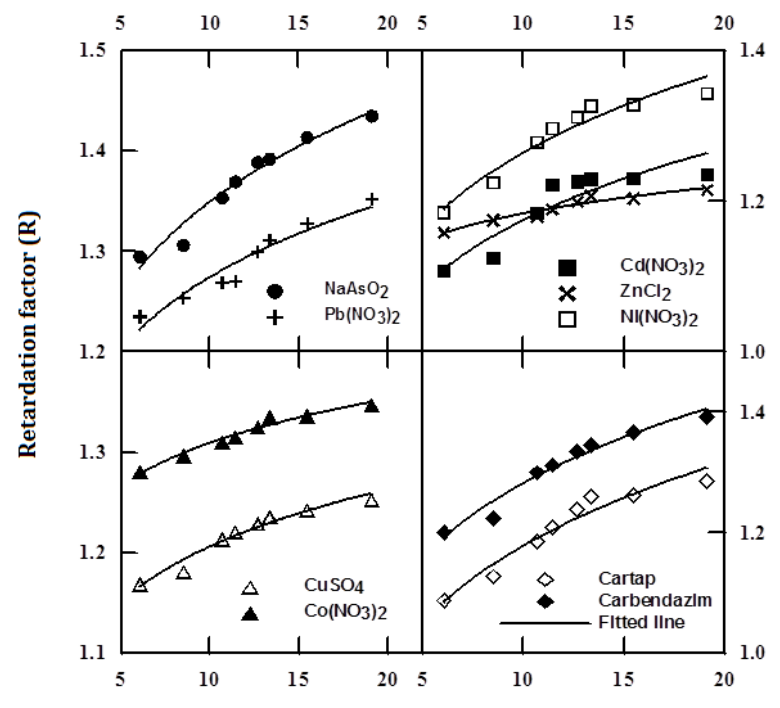

Clay content of soil (\%)

Figure 5. Variation of retardation factor $(R)$ with the clay content for different solutes through different textured soils at average water flux of $0.32 \mathrm{~cm} \mathrm{~h}^{-1}$

\section{Effect of pH on solute-transport parameters}

Soil $\mathrm{pH}$ contributed positively to velocity of solute, $V$, dispersion coefficient, $D$, and Peclet number, $P$. The correlations of $V$ and $P$ with $\mathrm{pH}$ were significant for the solute under investigation except for $\mathrm{CaCl}_{2}$ in case of $P$. But, the correlation of $D$ with $\mathrm{pH}$ was significant only for As, $\mathrm{Pb}$ and Co. The correlation of dispersivity, $\lambda$, and retardation factor, $R$, with soil $\mathrm{pH}$ was negative; the correlation of $\lambda$ with $\mathrm{pH}$ was significant except for $\mathrm{CaCl}_{2}$. Soil $\mathrm{pH}$ is one of the most important parameters affecting adsorption and ion-exchange properties of clay minerals. It partly determines the degree of surface charge on colloidal-sized soil particles. At high $\mathrm{pH}$, negatively charged surfaces develop, while at low $\mathrm{pH}$, positively charged surfaces occur. Consequently, the tendency for sorption of anions or cations is dependent on soil-water $\mathrm{pH}$. Soil $\mathrm{pH}$ also controls the accumulation, mobility and bio-availability of heavy metals and pesticides in soils. A decrease in pH elevates adsorption capacity of soils by which accumulation of heavy metals or pesticides is enhanced. The soils at Satkhira and Comilla with relatively low pH (6.85 and 6.32; Table 3) were characterized by higher level of 
adsorption than the other soils; the higher adsorption was manifested by higher values of the solute retardation factors in these soils. The adsorption of metals on the soils was high at $\mathrm{pH}$ below 7 , but it dropped considerably with the increase in $\mathrm{pH}$ above 7 . Consequently, soil $\mathrm{pH}(>7.0$ for six soils) contributed positively to the velocity of the solutes. As $\mathrm{pH}$ increased, the portion of positively charged surface sites on soil particles decreased with a consequent increased repulsion of anionic solute species and reduction of adsorption. Under this condition, adsorption of metals does not occur by electrostatic interaction, but can occur by specific chemical interaction between the negatively charged soil surface and the solute ions (Jain et al., 1999).

\section{Effects of organic carbon on solute-transport parameters}

Organic carbon, $\mathrm{C}$, in the soils improved structure of the repacked soils by enhancing soil aggregation, which enhanced solute movement through the soils. Consequently, velocity of the solutes, $V$, increased, to some extent, with the increase in C; the correlation between $V$ and $C$ was however insignificant $(r=0.013-0.048)$. The solute dispersion coefficient, $D$, and dispersivity, $\lambda$, were negatively and insignificantly correlated with $C$. This result agreed well with Hussein (2009), who reported smaller $\lambda$ in well-structured soils than in weakly structured soils. In the soils under investigation, the more C-containing soils having more stable structures than the less C-containing soils provided smaller $\lambda$ values. Our result was also very similar to that of Koestel et al. (2012), who observed no correlation between organic carbon content and dispersivity; in our case, the $r$ value was -0.034 to 0.234 .

Adsorption of solutes with soil minerals that depends on the type of solutes, and clay and organic matter contents of the soils govern solute retardation factor, $R$. Soil organic matter, due to its extensive surface area (Arthur et al., 2015; Jensen et al., 2015), surface properties and functional group, can serve as a buffer, an ion exchanger, a surfactant, a chelating agent and a general sorbent. All these properties of the organic matter played important role in the attenuation of the solutes in the soils. It is noted that the metal adsorption in the soils was related to soil organic matter content only at low metal loadings (Gao et al., 1997). Clay content of the soils played a more prominent role in accumulating heavy metals and pesticides in the soils. The relative importance of organic matter and clay in the adsorption of solutes in a soil depends on the ratio of clay content to organic carbon content (RCO) of the soil.

\section{Conclusion}

The dispersivity, $\lambda$, of one metalloid compound $\left(\mathrm{NaAsO}_{2}\right)$, six heavy metal compounds $\left(\mathrm{Cd}\left(\mathrm{NO}_{3}\right)_{2}, \mathrm{~Pb}\left(\mathrm{NO}_{3}\right)_{2}\right.$, $\mathrm{Ni}\left(\mathrm{NO}_{3}\right)_{2}, \mathrm{ZnCl}_{2}, \mathrm{CuSO}_{4}$ and $\left.\mathrm{Co}\left(\mathrm{NO}_{3}\right)_{2}\right)$ and two pesticides (cartap and carbendazim) in eight agricultural soils of Bangladesh was significantly $(\mathrm{p}<0.05)$ and positively correlated with clay content $(r=0.91-0.98)$ but negatively correlated ( $r=0.88-0.97)$ with median grain diameter of the soils; both functional relations were governed by power law. Solute retardation factor, $R$, also exhibited significant positive correlation $(r=0.92-$ 0.98 ) with clay content following power law variation. Column Peclet number, $P$, and solute velocity, $V$, had insignificant negative correlation with soil bulk density, $\rho$, while dispersion coefficient, $D$, and $\lambda$ were weakly and positively correlated with $\rho$. An increasing pore-size distribution index, $n$, proportionately reduced $\lambda$ but augmented $P$ with corresponding correlation range of $r=0.89$ to 0.99 and $r=0.82$ to 0.99 ; the correlation was significant $(\mathrm{p}<0.05)$ in both cases. $V$ and $P$ were positively and significantly correlated with soil $\mathrm{pH}$, while $R$ and $\lambda$ were negatively correlated with soil $\mathrm{pH}$; the correlation of $\lambda$ with $\mathrm{pH}$ was significant. Thus, the clay content, median grain diameter, pore-size distribution index, bulk density, organic carbon content and $\mathrm{pH}$ of the soils are the major factors that govern solute-transport parameters, mostly significantly, through the soils. The significant functional relations between the solute-transport parameters and governing soil properties demonstrate strong prospects of predicting solute-transport parameters from basic soil properties. The results described herein can thus serve as a dataset of transport experiments to develop more general pedo-transfer functions for solute-transport parameters that can significantly enhance prediction of pollution transport through soils.

\section{References}

Arora, K.R., 2000. Soil Mechanics and Foundation Engineering (Geotechnical Engineering). Standard Publishers, 5 Edition, 953p.

Arthur, E., Tuller, M., Moldrup, P., Jensen, D.K., De Jonge, L.W., 2015. Prediction of clay content from water vapour sorption isotherms considering hysteresis and soil organic matter content. European Journal of Soil Science 66(1): 206-217. 
BARC (Bangladesh Agricultural Research Council), 2008. National Agricultural Technology Project (NATP), Bangladesh. Phase-1 (IDA Credit \# 4386).

Bromly M., Hinz, C., Aylmore, L.A.G., 2007. Relation of dispersivity to properties of homogeneous saturated repacked soil columns. European Journal of Soil Science 58(1): 293-301.

BS 1377, 1990. Methods of test for soils for civil engineering purposes. Classification Tests. Parts 2 and 5. BS EN ISO 17892-5:2017.

de Jonge, L.W., Moldrup, P., Schjønning, P., 2009. Soil infrastructure, interfaces \& translocation processes in inner space ("Soil-it-is"): towards a road map for the constraints and crossroads of soil architecture and biophysical processes. Hydrology and Earth System Sciences 13(8): 1485-1502.

Filipović, V., Ondrašek, G., Filipović, L., 2016. Modelling water dynamics, transport processes and biogeochemical reactions in soil vadose zone. In: Groundwater - Contaminant and Resource Management. Javaid, M.S. (Ed.). InTech. pp. 133-167.

Gao, S., Walker, R.A., Dahlgren, W.J., Bold, J., 1997. Simultaneous sorption of $\mathrm{Cd}, \mathrm{Cu}, \mathrm{Ni}, \mathrm{Zn}, \mathrm{Pb}$, and $\mathrm{Cr}$ on soils treated with sewage sludge supernatant. Water, Air \& Soil Pollution 93(1-4): 331-345.

Guber, A., Pachepsky, Ya., Shein, E., Rawls, W.J., 2004. Soil aggregates and water retention. In: Development of Pedotransfer Functions in Soil Hydrology. Pachepsky, Y., Rawls, W.J. (Eds.). Elsevier, Amsterdam, The Netherlands. pp.143-152.

Hussein M.F., 2009. BTC solute-transport parameters for three sediments. 4th Conference on recent technologies in Agriculture, 3 November 2009. Cairo, Egypt.

Islam, M.R., Islam, S., Jahiruddin, M., Islam, M.A., 2004. Effects of irrigation water arsenic in the rice-rice cropping system. Journal of Biological Sciences 4(4): 542-546.

Jackson, M.L., 1962. Soil Chemical Analysis. Prentice Hall, Inc. Englewood Chiffs, New York, USA 498p.

Jain, A., Raven, K.P., Loeppert, R.H., 1999. Arsenite and arsenate adsorption on ferrihydrite: Surface charge reduction and net OH- release stoichiometry. Environmental Science \& Technology 33(8): 1179-1184.

Jensen, D.K., Tuller, M., de Jonge, L.W., Arthur, E., Moldrup, P., 2015. A New two-stage approach to predicting the soil water characteristic from saturation to oven-dryness. Journal of Hydrology 521: 498-507.

Karup, D., Moldrup, P., Paradelo, M., Katuwal, S., Norgaard, T., Greve, M.H., de Jonge, L.W., 2016. Water and solute transport in agricultural soils predicted by volumetric clay and silt contents. Journal of Contaminant Hydrology 192: 194-202.

Koestel, J.K., Moeys, J., Jarvis, N.J., 2012. Meta-analysis of the effects of soil properties, site factors and experimental conditions on solute transport. Hydrology and Earth System Sciences 16(6): 1647-1665.

Koestel, J.K., Norgaard, T., Luong, N.M., Vendelboe, A.L., Moldrup, P., Jarvis, N.J., Lamandé, M., Iversen, B.V., de Jonge. L.W., 2013. Links between soil properties and steady-state solute transport through cultivated topsoil at the field scale. Water Resources Research 49(2): 790-807.

Mojid, M.A., Rose, D.A., Wyseure, G.C.L., 2004. A transfer-function method for analysing breakthrough data in the time domain of the transport process. European Journal of Soil Science 55(4): 699-711.

Mojid, M.A., Hossain, A.B.M.Z., Cappuyns, V., Wyseure, G., 2016. Transport characteristics of heavy metals, metalloids and pesticides through major agricultural soils of Bangladesh as determined by TDR. Soil Research 54(8): 970984.

Mojid, M.A., Rose, D.A., Wyseure, G.C.L., 2006. Analysis of partial breakthrough data by a transfer-function method. Soil Research 44(2): 175-182.

Mojid, M.A., Vereecken, H. 2005a. Modelling velocity and retardation factor of a nonlinearly sorbing solute plume. Soil Research 43(6): 735-743.

Mojid, M.A., Vereecken, H., 2005b. On the physical meaning of retardation factor and velocity of a nonlinearly sorbing solute. Journal of Hydrology 302(1-4): 127-136.

Montoya, J.C., Costa, J.L., Liedl, R., Bedmar, F., Daniel, P., 2006. Effects of soil type and tillage practice on atrazine transport through intact soil cores. Geoderma 137(1-2): 161-173.

Mosaddeghi M.R., Khatar, M., Dexter, A.R., Mahboubi, A.A., 2008. Water characteristic curve and physical quality of soil as influenced by water salinity and sodicity. $2^{\text {nd }}$ International Salinity Forum Salinity, water and society-global issues, local action, Adelaide Convention Centre Adelaide, 31 March - 3 April 2008, South Australia.

Muchuweti, A., Birkett, J.W., Chinyanga, E., Zvauya, R., Scrimshaw, M.D., Lester, J.N., 2006. Heavy metal content of vegetables irrigated with mixtures of wastewater and sewage sludge in Zimbabwe: Implications for human health. Agriculture, Ecosystems \& Environment 112(1): 41-48.

Nemeth-Konda, L., Fuleky, G., Morovjan, G., Csokan, P., 2002. Sorption behaviour of acetochlor, atrazine, carbendazim, diazinon, imidacloprid and isoproturon on Hungarian agricultural soil. Chemosphere 48(5): 545-552.

Norgaard, T., Moldrup, P., Olsen, P., Vendelboe, A.L., Iversen, B.V., Greve, M.H., Kjaer, de Jonge, L.W., 2013. Comparative mapping of soil physical-chemical and structural parameters at field scale to identify zones of enhanced leaching risk. Journal of Environmental Quality 42(1): 271-283.

Okada, E., Costa, J.L., Bedmar, F., Barbagelata, P., Irizar, A., Rampoldi, E.A., 2014. Effect of conventional and no-till practices on solute transport in long term field trials. Soil and Tillage Research 142: 8-14. 
Page, A.L., Miller, R.H., Keeney, D.R., Baker, D.E., Ellis, R., Rhoades, J.D., 1982. Methods of Soil Analysis. eds (No. 631.41 MET 9-2 1982. CIMMYT.).

Pugliese, L., Straface, S., Trujillo, B.M., Poulsen, T.G., 2015. Relating non-equilibrium solute transport and porous media physical characteristics. Water, Air \& Soil Pollution 226, 59.

Raymundo-Raymundo, E., Nikolskii, Y.N., Guber, A.K., Landeros-Sanchez, C., 2012. Adequacy of transport parameters obtained in soil column experiments for selected chemicals. Eurasian Soil Science 45(7): 675-683.

Stavi, I., Ungar, E.D., Lavee, H., Sarah, P., 2011. Soil aggregate fraction 1-5 mm: An indicator for soil quality in rangelands. Journal of Arid Environments 75(11): 1050-1055.

Tabarzad, A., Sepaskhah, A.R., Farnoud, T., 2011. Determination of chemical transport properties for different textures of undisturbed soils. Archives of Agronomy and Soil Science 57(8): 915-930.

Taran, F., Nazemi, A.H., Sadraddini, A.A., Dinpazhuh, Y., 2015. Investigation of conservative and non-conservative solute transport in soil and comparison of three adsorption models using HYDRUS-2D. Journal of Materials and Environmental Science 7(6): 2082-2093.

Thawornchaisit, U., Polprasert, C., 2009. Evaluation of phosphate fertilizers for the stabilization of cadmium in highly contaminated soils. Journal of Hazardous Materials 165(1-3): 1109-1113.

van Genuchten, M.Th., 1980. A closed-form equation for predicting the hydraulic conductivity of unsaturated soils. Soil Science Society of America Journal 44(5): 892-898.

Vogel, H.J., Roth, K., 2003. Moving through scales of flow and transport in soil. Journal of Hydrology 272(1-4): 95-106.

Ward, A.L., Elrick, D.E., Kachanoski, R.G., 1994. Laboratory measurements of solute transport using time domain reflectometry. Soil Science Society of America Journal 58(4): 1031-1039.

Xu, M., Eckstein, Y., 1997. Statistical analysis of the relationships between dispersivity and other physical properties of porous media. Hydrogeology Journal 5(4): 4-20.

Li, Z.M., Zhou, Q., Wang, H., Lu, X., 2009. Influence of bulk density on the characteristic of water solute transport in red soil. Journal of Soil and Water Conservation 23: 101-103. 